\title{
Nutrients Use Efficiency of Different Crop Residues Management Techniques under Wheat-Rice Cropping System in Semi Arid Climate
}

\author{
Aamer Sattar ${ }^{1}$, Sadia Sultana ${ }^{*}$, Abid Niaz ${ }^{1}$, Muhammad Aftab ${ }^{1}$, Ghulam Sarwar ${ }^{2}$, Irfan Rasheed ${ }^{3}$, \\ Muhammad Shoaib ${ }^{4}$, Raheela Naz ${ }^{1}$, Amina Kalsom ${ }^{1}$, Nisa Mukhtar ${ }^{1}$, Farah Rasheed ${ }^{1}$, Arfan ul Haq ${ }^{1}$, \\ Munazza Rafique ${ }^{5}$, Muhammad Arif ${ }^{1}$, Sarfraz Hussain ${ }^{1}$ and Jafar Salim ${ }^{6}$
}

${ }^{1}$ Soil Chemistry Section, Institute of Soil and Environmental Sciences, AARI, Faisalabad, Pakistan; ${ }^{2}$ Department of Soil and Environmental Sciences, College of Agriculture, University of Sargodha, Sargodha, Pakistan; ${ }^{3}$ Pesticides Quality Control Laboratory, Institute of Soil and Environmental Sciences, AARI, Faisalabad, Pakistan; ${ }^{4}$ Maize and Millets Research Institute, Yusafwala, Pakistan; ${ }^{5}$ Soil Bacteriology Section, Agricultural Biotechnology Research Institute, Ayub Agricultural Research Institute; ${ }^{6}$ Statistical Section, Ayub Agricultural Research Institute.

\begin{abstract}
Burning of crop residues in semi-arid region with hot climate and less than $1 \%$ soil organic matter not only pose severe threat to global climate but also become the reason of ever decreasing organic matter status. Keeping in view the objective to monitor the impacts of crop resides, burning and incorporation into the soil on crop yield, nutrients uptake and soil physico-chemical properties, this long-term study was planned and conducted at Soil Chemistry Section, Ayub Agricultural Research Institute, Faisalabad. Four treatments (sub plots) viz; 0 fertilizer, $50 \%$ of recommended fertilizer, $75 \%$ of recommended fertilizer and $100 \%$ of recommended fertilizer were applied under split plot design repeated thrice with 3 major plots (methods of residues management) i. traditional practice by complete removing (C) whole crop biomass from field, ii. burnt (B) practice by burning the crop biomass in field after threshing and iii. Residue's (R) incorporation practice by rotavating the crop biomass into the soil. The selected field was sufficient in exchangeable $\mathrm{K}$ and available $\mathrm{P}$ but was deficient in organic matter contents. The results showed that in first year the wheat yield was maximum in $\mathrm{T}_{4}\left(5.04 \mathrm{t} \mathrm{ha}^{-1}\right)$ in complete removal plot followed by residues incorporated $\left(4.43 \mathrm{tha}^{-1}\right)$ and burnt plots $\left(3.72 \mathrm{t} \mathrm{ha}^{-1}\right)$ respectively. It was observed that yield in residues incorporated plots was declined in next year after that, an increasing trend was witnessed. Burning of residues caused decrease in yield up to $11 \%$ as compared to complete removal and up to $17 \%$ than residues incorporation. Organic matter status of soil before start of experiment was $0.69 \%$. Mean organic matter contents in residues incorporated plots was increased up to $27 \%$ than complete removal and up to $32 \%$ than burnt plots. Nitrogen and phosphorus uptake were maximum in residues incorporated plots followed by complete removal and burnt plots, however potassium uptake was maximum in complete removal followed by residues incorporated and burnt plots. ECe of burnt plots was increased by $100 \mathrm{dS} \mathrm{m} \mathrm{m}^{-1}$ than complete removal and $200 \mathrm{dS} \mathrm{m}^{-1}$ than residues incorporated plots. Other physicochemical properties were not affected significantly.

Received | March 01, 2021; Accepted | March 28, 2021; Published | June 03, 2021

*Correspondence | Sadia Sultana, Soil Chemistry Section, Institute of Soil and Environmental Sciences, AARI, Faisalabad, Pakistan; Email: sadia_agri@yahoo.com

Citation | Sattar, A., S. Sultana, A. Niaz, M. Aftab, G. Sarwar, I. Rasheed, M. Shoaib, R. Naz, A. Kalsom, N. Mukhtar, F. Rasheed, A. Haq, M. Rafique, M. Arif, S. Hussain and J. Salim. 2021. Nutrients use efficiency of different crop residues management techniques under wheat-rice cropping system in semi arid climate. Pakistan Journal of Agricultural Research, 34(2): 444-453.

DOI | http://dx.doi.org/10.17582/journal.pjar/2021/34.2.444.453

Keywords | Nutrients, Efficiency, Residues management
\end{abstract}

June 2021 | Volume 34 | Issue 2 | Page 444 
Introduction

$\mathrm{C}_{\mathrm{f}}^{\mathrm{n}}$ rop residues and waste management is a big problem faced by the farmers of developing and under developed countries. In Pakistan, more than 65-thousand-ton rice residues and 24-thousand-ton wheat residues are produced each year. Handling of this much amount of residue is a giant issue that is still unattended. Many local farmers use to burn crop residues before next crop. Rice is a second staple food of Pakistan which is cultivated on about $2.7 \times 10^{3}$ thousand hectares each year while wheat is cultivated on more than $8.7 \times 10^{3}$ thousand hectares in Pakistan (GOP, 2020). Crop residues of both are used in different ways including feed and bedding material for animals, building materials for humans and nutrients reservoir for soil. However, in spite of the benefits of the crop's residues, some farmers get rid of entire residues by burning them prior of next corp. Without degrading the environment, now a-days a big challenge for agriculture is to provide enough food for ensuring food security of ever-increasing population (Stevenson et al., 2013). Moreover, changes in climate are casting drastic effect on environment, so in this situation sustainable food production is a big chore for the farmer (Palm et al., 2013; Paudel et al., 2014). Carbon sequestration is a main tool of sustainable agriculture and climate change mitigation and it is a leading agricultural strategy to alleviate greenhouse gases emission, ensure food security, and maintain sustained agriculture (Rajan et al., 2016). It is observed that crop residues burning increase the phosphorus and potassium over certain period of time, yet there may be loss of nitrogen and sulphur (Erenstein, 2002; Gupta et al., 2004). There may also be the depletion of indigenous micro biota along with lost organic carbon (Heard et al., 2006). In contrast to burning of crop residues, their incorporation into the soil improves organic matter status of soil which not only improves soil properties but also harbors indigenous soil microbial populations which bring about the nutrient recycling. It ensures sustained and continuous supply of nutrients for different growth stages of plants (Hartley and Kessel, 2005). All these processes procure higher crop yield (Surekha et al., 2003) through better nutrients uptake, especially improved nitrogen $(\mathrm{N})$ uptake (Verma and Bhagat, 1992). The soil dynamics for organic carbon depends mainly upon nutrients management practices like tillage and crop residues incorporation in soil. Hence, under rice-wheat cropping rotation system in Pakistan, better management practices like better crop rotation, reduced or minimum tillage, adequate nutrient supply and crop residues incorporation can increase the soil organic matter and guarantees sustainable agriculture (Vanden et al., 2003). In a cropping system where few inputs are used crop remains a vibrant source of nutrients supply (Nyborg et al., 1995). While, burning of paddy straw results in loss of about $4 \mathrm{Mt}$ of OC (organic matter), 9000, 20,000 and 34000 ton of N, P and K, respectively (Kumar, 2014).

In subcontinent, burning is a conventional practice to get rid of huge leftover after crop harvesting. As it is also relatively cheap and fast method. Farmers are reluctant to incorporate the rice residues into the field as its decomposition in winter tends to be slower due the low temperature. So, a long-term study was planned and conducted to compare the effect of three methods of residues management (traditional practice by complete removal of all biomass from field, burnt practice by burning the biomass in field after threshing and residues incorporate practices by rotavating the biomass in field) prevailing in Pakistan. The main objectives of the study were to assess the role of crop residues on soil management and different level of fertilizers on soil properties as well as on the nutrients use efficiency under wheat-rice cropping system (Soon, 1998).

\section{Materials and Methods}

\section{Experimental site}

A long-term study consisting of consecutive six years from 2014 to 2020 was executed at the farm area of Institute of Soil Chemistry and Environmental Sciences (ISC and ES), Ayub Agricultural Research Institute (AARI), Pakistan $\quad\left(073^{\circ} 03.173^{\circ} \mathrm{E}\right.$, $\left.31^{\circ} 23.968^{`} \mathrm{~N}\right)$.

\section{Layout and fertilization}

3 plots were identified for residues management practices; traditional practice by Complete removing (C) the biomass from field, burnt (B) practice by burning the biomass in field after threshing and residue's $(R)$ incorporation practices by rotavating the biomass into the filed prior to sowing. Treatment's plan consisted of: $\mathrm{T}_{1}=$ Control, $\mathrm{T}_{2}=50 \%$ of residues + $\mathrm{NPK}, \mathrm{T}_{3}=75 \%$ of residues $+\mathrm{NPK}$ and $\mathrm{T}_{4}=100 \%$ of residues + NPK. Urea, single superphosphate (SSP) and sulfate of potash (SOP) were used as nitrogenous, phosphatic and potassic sources, respectively. Half 
nitrogen and full phosphorus and potassium doses were used as basal dose (at the time of sowing). While remaining second half of $\mathrm{N}$ was fertilized at first irrigation. Galaxy, wheat variety was sown with drill and plant-plant distance was 9 inches. All treatments were applied in permanent lay out under Split Plot RCBD (Randomized Complete Block Design) with three main plots, four treatments and three replications.

\section{Soil and plant analysis}

Soil samples from two depths $(0-15 \mathrm{~cm}$ and $15-30$ $\mathrm{cm})$ were taken from experimental site according to zigzag sampling method before transplanting of rice seedling and after harvesting of crop. Hydrometer method was employed for characterizing the textural class of the soil (Blake and Hartge, 1986). Jenway-3510 pH meter and Jenway-4510 EC meter were used for $\mathrm{pH}$ and $\mathrm{EC}_{\mathrm{e}}$ determination, respectively (Mclean, 1982). Soil organic carbon was estimated following the method described by Ryan et al. (2001). Olsen's method (Jackson, 1962) and $\mathrm{CH}_{3} \mathrm{COONH}_{4}$ extraction method (Rowell, 1994) were practiced for available $\mathrm{P}$ and extractable $\mathrm{K}$, respectively. Moisture content in soil samples was determined by gravitational method as described by Sparks et al. (1996).

Wheat crop from whole plot $\left(7 \times 5 \mathrm{~m}^{2}\right)$ was harvested and yield per hectare was calculated. Grain and straw samples were collected and fresh weight was recorded. Then these samples were placed in an oven at $65 \pm 5^{\circ} \mathrm{C}$ for $24 \mathrm{hrs}$. till constant weight, oven dry weight was recoded and moisture contents in grain and straw were calculated. After drying, samples were ground for further analysis. Total $\mathrm{N}$ was determined by Kjeldahl method (Jackson, 1962). Samples were prepared after wet digestion (Chapman and Pratt, 1961) for the determination of plant $\mathrm{P}$ and $\mathrm{K}$ by spectrophotometer (U-2020) and flame photometer (Jenway-PFP7), respectively. Nutrient uptake by wheat crop was determined on dry weight basis using the following relationship (Fegeria et al., 1997).

Nutrient uptake $=($ Nutrient Concentration $(\%) \times$ dry yield $) / 100$

\section{Statistical analysis}

The experimental data were subjected to statistical analysis of variance ANOVA (Fisher's analysis) using least significance difference test (LSD) for comparing treatment means at 5\% probability (Steel et al., 1997).
Results and Discussion

\section{Pre-sowing soil properties}

The experimental site was observed sufficient in extractable potassium $(\mathrm{K})$ and available phosphorus (P) while it was found deficient in organic matter (OM). Soil was classified as sandy clay loam for its texture (Table 1). The soil analysis showed that soil was alkaline in reactions and poor in soil fertility.

$\begin{array}{lll}\text { Table 1: Pre- Sowing Soil Physico-chemical } & \text { properties. } \\ \text { Parameters } & \text { Unit } & \text { Value } \\ \text { Sand } & \% & 51.5 \\ \text { Silt } & \% & 19 \\ \text { Clay } & \% & 29.5 \\ \text { Texture } & \text { Sandy clay loam } & \\ \text { Soil Saturation } & \% & 30.5 \\ \mathrm{pH} & - & 7.84 \\ \text { ECe } & \mathrm{dS} \mathrm{m}^{-1} & 1.17 \\ \text { K } & \mathrm{mg} \mathrm{kg}^{-1} & 220 \\ \text { P } & & 8.31 \\ \text { Organic matter } & \% & 0.68\end{array}$

Effect of crop residues management techniques on soil nutrients status

Soil organic matter: Post-harvest soil analysis (Figure 1) shows that after first year of experiment, soil organic matter content in the plots where crop residues were completely removed was $0.57 \%$ in $\mathrm{CT}_{1}$, while $\mathrm{CT}_{2}$ and $\mathrm{CT}_{3}$ were at par $(0.60 \%)$ with each other, however in $\mathrm{CT}_{4} 0.70 \%$ organic matter was detected.

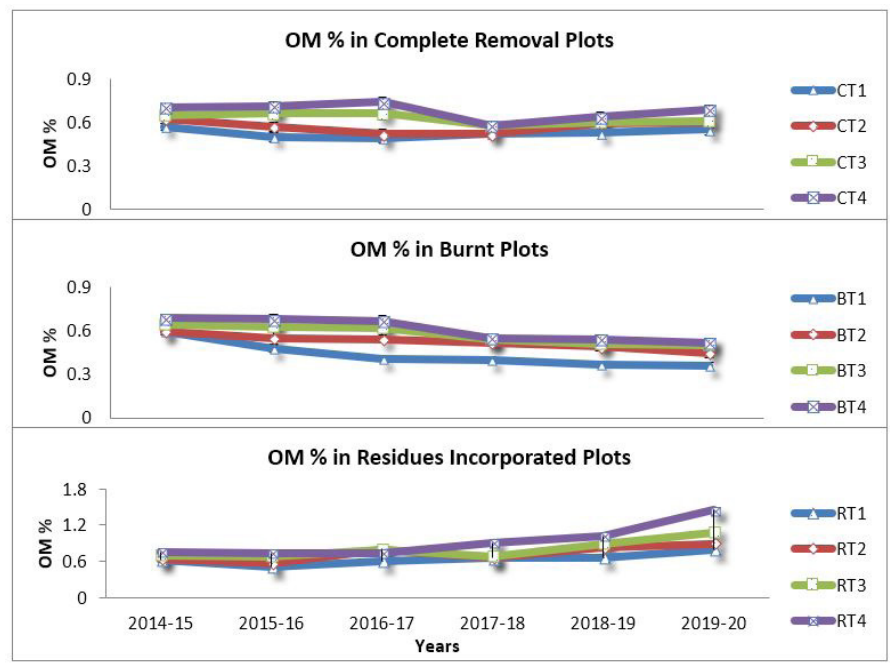

Figure 1: Effect of Residues Management techniques on Soil organic matter contents (\%) (depth $0-15 \mathrm{~cm})$.

Next year (2015-16) CT $_{1}$ showed decline trend 
$(0.35 \%)$ while other treatments remained constant. In 2017-18, treatment effect was vanished and $0.5 \%$ organic matter was detected in all treatments however, after that increasing trend was observed in all treatments but $\mathrm{CT}_{4}$ restored its initial organic matter status $(0.69 \%)$ in 2019-20. In burnt plots, organic matter contents in $2014-15$ was $0.6 \%$ in all treatments which tended to decrease in $\mathrm{BT}_{1}$ and $\mathrm{BT}_{2}$ through next two years but fertilizer application in $\mathrm{BT}_{3}$ and $\mathrm{BT}_{4}$ kept the organic matter contents constant. In third year (2017-18) treatment effect was disappeared and $\mathrm{BT}_{2}, \mathrm{BT}_{3}$ and $\mathrm{BT}_{4}$ were at par with each other. It was observed that addition of fertilizers kept the organic matter at $0.5 \%$ while zero control was severely deficient in organic matter $(0.36 \%)$. On the other hand, residues incorporated plots behaved differently. After first year, 0.6 and $0.7 \%$ organic matter contents were detected in $\mathrm{RT}_{1}, \mathrm{RT}_{2}, \mathrm{RT}_{3}$ and $\mathrm{RT}_{4}$, respectively. However, there was a huge decline in organic matter contents $(0.39 \%)$ in $\mathrm{RT}_{1}$ and minor decline was observed in other treatments. It might be due to the accumulation of organic matter in soil (Hossein and Bahrani, 2009). After 6 years of residues incorporation, soil fertility was improved by increased organic matter contents by $0.9 \%$.

Comparison of all three management practices reveled that plots with complete removal of residues had 1 to $6 \%$ more OM however as compared to residues incorporated plots about 30\% less OM contents were present in complete removal plots. When burnt practice was compared with residues incorporation practice, it was found that in $\mathrm{T}_{1}$ and $\mathrm{T}_{2} 30 \%$ less
OM contents were present and in $\mathrm{T}_{3}$ and $\mathrm{T}_{4} 37$ and $46 \%$ less organic matter contents were detected. So, it can be supposed that by incorporating the crop residues into the soil, OM contents in control where no fertilizer was added were 23 and $24 \%$ greater than complete removal and burnt plots. Application of fertilizer along with incorporating the residues increased the organic matter contents by 21 to $31 \%$ as compared to complete removal and burnt practices.

\section{$\mathrm{NaHCO}_{3}$ extractable phosphorus \\ $\mathrm{C}=$ Complete Removal, $\mathrm{B}=$ Burnt, $\mathrm{R}=$ Residues Incorporation}

\section{Olsen $P$}

Data exhibited that burning of residues improved soil-P by 2 to $4 \%$. However, residues incorporation increased the phosphorus contents. The residues incorporation increases the crop available $\mathrm{P}$ by organic matter decomposition and release of $\mathrm{P}$ during this process along with desorption of rock phosphate by increasing the organic acids in soil (Nziguheba et al., 1998). Data (Table 2) reveled that soil available phosphorus was increased in all plots with the time and in 2019-20, phosphorus contents were almost 3 folds of 2014-15. Treatment's effect was also visible. Application of fertilizer had significant effect on available phosphorus. Comparison of three residues management practices showed that burning of crop residues increased the available $\mathrm{P}$ contents $(2-4 \%)$ as compared to completely removing the residues but 6-11\% decrease was observed in comparison with residues incorporation practice in all treatments.

Table 2: Residues management practices effect on soil Phosphorus $(0-15 \mathrm{~cm})$.

\begin{tabular}{|c|c|c|c|c|c|c|c|c|c|c|}
\hline & 2014-15 & 2015-16 & 2016-17 & 2017-18 & 2018-19 & 2019-20 & Mean & $\begin{array}{l}\text { \% change } \\
\text { over } \mathrm{C}\end{array}$ & $\begin{array}{l}\% \text { change } \\
\text { over B }\end{array}$ & $\begin{array}{l}\% \text { change } \\
\text { over } R\end{array}$ \\
\hline CT1 & $5.45 \pm 0.08$ & $7.6 \pm 1.05$ & $10.2 \pm 1.37$ & $9.81 \pm 0.33$ & $15.3 \pm 0.29$ & $16.5 \pm 0.15$ & 10.8 & 0 & -2.87 & -11.5 \\
\hline CT2 & $6.73 \pm 0.02$ & $7.82 \pm 0.53$ & $11.2 \pm 2.48$ & $15.1 \pm 0.30$ & $16.1 \pm 0.82$ & $17.4 \pm 0.31$ & 12.4 & 0 & -3.11 & -16.2 \\
\hline CT3 & $7.1 \pm 0.04$ & $7.9 \pm 0.20$ & $12.1 \pm 1.90$ & $17.6 \pm 1.15$ & $21.2 \pm 0.17$ & $18.2 \pm 0.31$ & 14.0 & 0 & -4.15 & -11.0 \\
\hline CT4 & $8.11 \pm 0.10$ & $8.12 \pm 0.26$ & $12.8 \pm 1.72$ & $20.9 \pm 0.49$ & $23.6 \pm 1.40$ & $25.2 \pm 0.42$ & 16.5 & 0 & -2.25 & -14.4 \\
\hline BT1 & $5.21 \pm 0.02$ & $5.91 \pm 1.52$ & $10 \pm 1.37$ & $11.5 \pm 0.95$ & $16.3 \pm 0.95$ & $17.8 \pm 0.15$ & 11.1 & 2.8 & 0.0 & -8.4 \\
\hline BT2 & $5.74 \pm 0.04$ & $6.92 \pm 0.53$ & $12.2 \pm 2.48$ & $10.2 \pm 1.19$ & $21.5 \pm 1.63$ & $20.1 \pm 0.55$ & 12.8 & 3.0 & 0.0 & -12.7 \\
\hline BT3 & $5.97 \pm 0.04$ & $8.02 \pm 1.48$ & $13.4 \pm 1.90$ & $12.7 \pm 1.25$ & $22.6 \pm 0.08$ & $24.9 \pm 0.47$ & 14.6 & 4.0 & 0.0 & -6.6 \\
\hline BT4 & $6.24 \pm 0.10$ & $8.41 \pm 2.56$ & $14.3 \pm 1.72$ & $16.4 \pm 0.92$ & $25.8 \pm 0.45$ & $29.8 \pm 0.07$ & 16.8 & 2.2 & 0.0 & -11.8 \\
\hline RT1 & $7.88 \pm 0.03$ & $7.84 \pm 0.96$ & $7.62 \pm 0.45$ & $10.2 \pm 0.75$ & $18.3 \pm 1.19$ & $20.5 \pm 1.04$ & 12.1 & 10.3 & 7.8 & 0.0 \\
\hline RT2 & $8.29 \pm 0.03$ & $9.12 \pm 1.03$ & $12.1 \pm 1.18$ & $12.6 \pm 0.34$ & $21.2 \pm 0.51$ & $23.1 \pm 0.47$ & 14.4 & 14.0 & 11.3 & 0.0 \\
\hline RT3 & $8.63 \pm 0.04$ & $10.4 \pm 1.28$ & $14.6 \pm 1.52$ & $13.3 \pm 0.74$ & $22.1 \pm 1.21$ & $24.3 \pm 0.15$ & 15.6 & 9.9 & 6.2 & 0.0 \\
\hline RT4 & $9.31 \pm 0.07$ & $11.5 \pm 2.56$ & $17.9 \pm 2.52$ & $14.9 \pm 0.96$ & $28.8 \pm 0.78$ & $30.5 \pm 1.04$ & 18.8 & 12.6 & 10.6 & 0.0 \\
\hline
\end{tabular}


$\mathrm{NH}_{4} \mathrm{C}_{2} \mathrm{H}_{3} \mathrm{O}_{2}$ extractable potassium

Soil analysis before the start of the experiment revealed that $220 \mathrm{mg} / \mathrm{kg}$ extractable $\mathrm{K}$ was available however, after the harvesting of first season crop, a different scenario was observed (Figure 2). In plots where crop residues were removed, non-addition of fertilizer caused to decrease K contents $(190 \mathrm{mg} / \mathrm{kg})$, but additions of fertilizer tended to keep the original concentration constant. After that, an increasing trend was observed in all practices and in all treatments. It was observed that burning of crop resides increased $\mathrm{K}$ contents by 6-10\% over complete removal. However, incorporation of residues increased $\mathrm{K}$ contents about $12 \%$ over complete removal and $2-6 \%$ over burning practice.

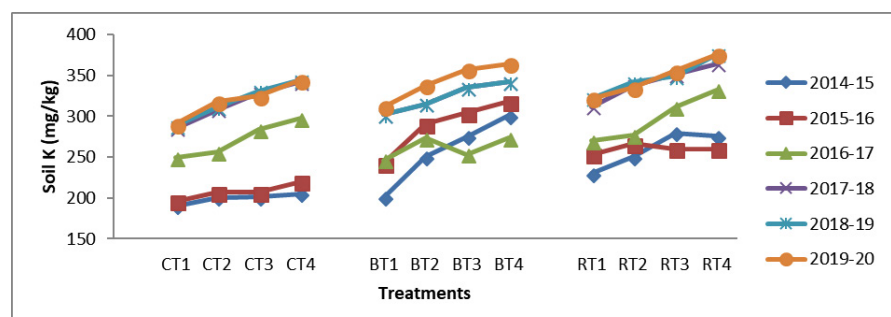

Figure 2: Effect of residues management practices on extractable $K$ contents.

\section{Soil chemical properties}

Post-harvest soil analysis (Table 3) showed that residues management practices had a non-significant effect on water holding capacity and it was 7, 7.2 and $7.4 \mathrm{ml} / \mathrm{L}$ in complete removal, burnt and residues incorporation plots respectively. However, bulk density (BD) and moisture percentage was not been affected by residues management techniques. $\mathrm{pH}$ in burnt plot was 8.1 while in other two plots, it was 8.2. Soil ECe was affected the most by burning the crop residues than complete removal and residues incorporation.

Table 3: Effect of residues management practices on Soil properties after $6^{\text {th }}$ Year.

$\begin{array}{llllll} & \begin{array}{l}\text { WHC } \\ (\mathbf{m l} / \mathbf{L})\end{array} & \text { BD } & \begin{array}{l}\text { Moisture con- } \\ \text { tents (\%) }\end{array} & \mathbf{p H} & \begin{array}{l}\mathbf{E C e} \\ \mathbf{( d S / m )}\end{array} \\ \mathrm{C} & 7.0 & 1.20 & 35.5 & 8.2 & 1469.1 \\ \mathrm{~B} & 7.2 & 1.23 & 36.2 & 8.1 & 1570.7 \\ \mathrm{R} & 7.4 & 1.24 & 36.7 & 8.2 & 1303.7\end{array}$

\section{Effect of crop residues management techniques on yield}

The six years results (Table 4) showed that crops residues management techniques and fertilizers rates had significant influence on wheat grain and biomass yield. Incorporation of crops residues decreased the yield first year which is similar to the results of Rieger et al. (2008) then an increasing trend was noticed which is analogous to the results of Hossein and Bahrani (2009).

In 2014-15, data of first wheat crop after rice residues treatment showed significant variation. The plots where rice residues were completely removed performed best as compared to the burnt and residues incorporated plots. Wheat yield recorded in $\mathrm{CT}_{1}$ was $2.82 \mathrm{tha}^{-1}$ where no fertilizer was added while in $\mathrm{CT}_{4}$,

Table 4: Effect of residues management practices on wheat yield.

\begin{tabular}{|c|c|c|c|c|c|c|c|c|c|c|}
\hline & 2014-15 & 2015-16 & 2016-17 & 2017-18 & 2018-19 & 2019-20 & Mean & $\begin{array}{l}\text { \% change } \\
\text { over } \mathrm{C}\end{array}$ & $\begin{array}{l}\% \text { change } \\
\text { over B }\end{array}$ & $\begin{array}{l}\% \text { change } \\
\text { over } \mathrm{R}\end{array}$ \\
\hline${ }^{*} \mathrm{CT} 1$ & $2.082 \mathrm{~F}$ & $1.92 \mathrm{E}$ & $1.32 \mathrm{H}$ & $2.09 \mathrm{D}$ & $3.57 \mathrm{CDE}$ & $2.94 \mathrm{H}$ & 2.45 & - & 10.4 & -5.11 \\
\hline CT2 & $4.3 \mathrm{C}$ & $2.68 \mathrm{D}$ & $2.64 \mathrm{G}$ & $2.71 \mathrm{BCD}$ & $3.86 \mathrm{BCD}$ & $3.58 \mathrm{FG}$ & 3.3 & - & 2.1 & -5.24 \\
\hline CT3 & $4.59 \mathrm{~B}$ & $3.15 \mathrm{C}$ & $3.49 \mathrm{DE}$ & $3.76 \mathrm{~A}$ & $4.23 \mathrm{AB}$ & 3.99 DEF & 3.87 & - & 9.1 & 1.76 \\
\hline CT4 & $5.04 \mathrm{~A}$ & $3.78 \mathrm{AB}$ & $3.80 \mathrm{~A}$ & $4.49 \mathrm{~A}$ & $4.57 \mathrm{~A}$ & $4.70 \mathrm{AB}$ & 4.4 & - & 9.5 & 0.45 \\
\hline "BT1 & $1.76 \mathrm{H}$ & $1.61 \mathrm{EF}$ & $1.58 \mathrm{H}$ & $2.03 \mathrm{D}$ & $3.03 \mathrm{~F}$ & $3.12 \mathrm{H}$ & 2.19 & -11.6 & - & -17.3 \\
\hline BT2 & $3.22 \mathrm{E}$ & $2.88 \mathrm{CD}$ & $3.15 \mathrm{EF}$ & $3.26 \mathrm{ABC}$ & $3.16 \mathrm{EF}$ & $3.69 \mathrm{EFG}$ & 3.23 & -2.1 & - & -7.4 \\
\hline BT3 & $3.34 \mathrm{E}$ & $3.17 \mathrm{C}$ & $3.70 \mathrm{CD}$ & $3.30 \mathrm{ABC}$ & $3.40 \mathrm{DEF}$ & $4.20 \mathrm{CD}$ & 3.52 & -10.0 & - & -8.1 \\
\hline BT4 & $3.72 \mathrm{D}$ & $3.61 \mathrm{~B}$ & $4.09 \mathrm{BC}$ & $3.66 \mathrm{AB}$ & $3.93 \mathrm{BC}$ & $4.87 \mathrm{AB}$ & 3.98 & -10.4 & - & -9.9 \\
\hline "RT1 & $2.4 \mathrm{G}$ & $1.54 \mathrm{~F}$ & $2.78 \mathrm{FG}$ & $2.43 \mathrm{CD}$ & $2.91 \mathrm{~F}$ & $3.35 \mathrm{GH}$ & 2.57 & 4.9 & 14.8 & - \\
\hline RT2 & $3.36 \mathrm{E}$ & $2.59 \mathrm{D}$ & $3.83 \mathrm{CD}$ & $3.60 \mathrm{AB}$ & $3.33 \mathrm{EF}$ & 4.10 CDE & 3.47 & 5.0 & 6.9 & - \\
\hline RT3 & $3.87 \mathrm{D}$ & $3.05 \mathrm{C}$ & $3.36 \mathrm{EF}$ & $3.66 \mathrm{AB}$ & $4.34 \mathrm{AB}$ & $4.52 \mathrm{BC}$ & 3.8 & -1.8 & 7.5 & - \\
\hline RT4 & $4.43 \mathrm{BC}$ & $3.99 \mathrm{~A}$ & $3.98 \mathrm{BC}$ & $4.10 \mathrm{~A}$ & $4.73 \mathrm{~A}$ & $5.02 \mathrm{~A}$ & 4.38 & -0.5 & 9 & - \\
\hline LSD Plot & 0.26 & 0.60 & 0.47 & 0.35 & 0.25 & 0.189 & - & - & & \\
\hline LSD Trt & 0.23 & 0.24 & 0.21 & 0.431 & 0.28 & 0.261 & - & - & & \\
\hline
\end{tabular}


where 100\% recommended fertilizer was added, 5.04 $\mathrm{t} \mathrm{ha}^{-1}$ yield was observed followed by $\mathrm{CT}_{3}\left(4.59 \mathrm{t} \mathrm{ha}^{-1}\right)$ and $\mathrm{CT}_{4}\left(4.3 \mathrm{tha}^{-1}\right)$. Next year, 32\% yield was decreased in $\mathrm{CT}_{1}$ and $37 \%, 31 \%$ and $25 \%$ reduction in yield was observed in $\mathrm{CT}_{2}, \mathrm{CT}_{3}$ and $\mathrm{CT}_{4}$, respectively. In 201617 again fall in yield was witnessed in $\mathrm{CT}_{1}$ and $\mathrm{CT}_{2}$, while in $\mathrm{CT}_{3}$ yield was increased and in $\mathrm{CT}_{4}$ the yield was at par with the previous year yield. After that an upward shift in yield data was experimented for all treatments in all three years and in 2019-20, 2.45 tha ${ }^{-1}$ yield was in control where no fertilizer was added. Data also depicted that treatments had a significant effect on wheat yield. While, in plots where rice residues were burnt and ash was incorporated into the soil, in first year of burning, control plot $\left(\mathrm{BT}_{1}\right)$ showed yield $1.76 \mathrm{t} \mathrm{ha}^{-1}$, addition of $50 \%$ recommended fertilizer increased the yield by two folds $\left(3.22 \mathrm{t} \mathrm{ha}^{-1}\right)$ over control, however further increase in fertilizer had no effect on yield. Addition of $100 \%$ fertilizer increased the yield by $47 \%$ as compared to control. Next year, the yield was slightly decreased in all treatments then mixed trend prevailed in all treatments.

In residues incorporated plots, whole rice plant residues were incorporated into the soil and urea was added at the rate of $1 \mathrm{bag}$ acre ${ }^{-1}$ to stimulate the breakdown of residues completely, however, as rice chopper was not available with the farm area, so it was observed that, rice straw remained in the soil till the maturity of wheat crop. But still, increase in yield was observed in all plots as compared to burnt plots. In $\mathrm{RT}_{1}$ (zero control) yield was $2.44 \mathrm{t} \mathrm{ha}^{-1}$ which was $37.5 \%$ more than the burnt zero control $\mathrm{BT}_{1}$. Addition of 50 recommended fertilizers increased the yield by $40 \%$. Further addition of fertilizer boosted the yield by $61 \%$ and application of recommended fertilizer increased the yield by $84 \%$ over zero control. However, in second year the grain yield was dropped in all treatments significantly in comparison to first year owing to crop residues buildup (Asal et al., 2015). In third year, yield was increased in $\mathrm{RT}_{1}, \mathrm{RT}_{2}$ and $\mathrm{RT}_{3}$ but in $\mathrm{RT}_{4}$ the yield was at par with previous year. In 2017-18 due to some unknown factors, yield was dropped in $\mathrm{RT}_{1}$ and $\mathrm{RT}_{2}$ by 12 and $6 \%$ respectively but in $\mathrm{RT}_{3}$ the yield was increased by $8.9 \%$. In $\mathrm{RT}_{4}$ the yield was at par with previous two years. After that an upward shift was obvious in all treatments. Comparison of the complete removal and burning method showed that burning of residues dropped the yield by $11 \%$ in the treatment where no fertilizer was added. In $\mathrm{BT}_{2}$ the yield was decreased by $2 \%$ while in $\mathrm{BT}_{3}$ and $\mathrm{BT}_{4}$ about $10 \%$ yield was declined relative to the complete residue's removal. On the other hand, residues incorporation increased the yield by about $14.8 \%$ in $\mathrm{RT}_{1}$ where no fertilizer was added and $6.9 \%$ in $\mathrm{RT}_{2}, 7.5 \%$ in $\mathrm{RT}_{3}$ and $9 \%$ in $\mathrm{RT}_{4}$ as compared to the burnt plots.

\section{Effect of crop residues management techniques on} macronutrients concentration in grain

Wheat grain analysis for $\mathrm{N}$ contents (Figure 3) reveled that mean nitrogen contents were increased in all treatments with the increase in applied fertilizers concentration. However, grain $\mathrm{N}$ contents were not affected by the residue management techniques. in complete removal plots mean $\mathrm{N}$ contests were higher $(1.28 \%)$ than burnt $(1.15 \%)$ and residues incorporated plots (1.08\%). Similarly, Phosphorus contents in wheat grain were relatively un-effected by the crop residues management techniques (Figure 3). In complete removal plots average $\mathrm{P}$ contents in grain were $0.35 \%$, in burnt plots $0.39 \%$ and in residues incorporated plots $40 \%$. Application of fertilizers had contributing effect on $\mathrm{K}$ contents in wheat grain. Minimum potassium concentration was $0.45 \%$ in plot where no fertilizer was added while maximum $\mathrm{K}(0.71 \%)$ was detected in the treatment where recommended amount of fertilizers was applied (Figure 3).

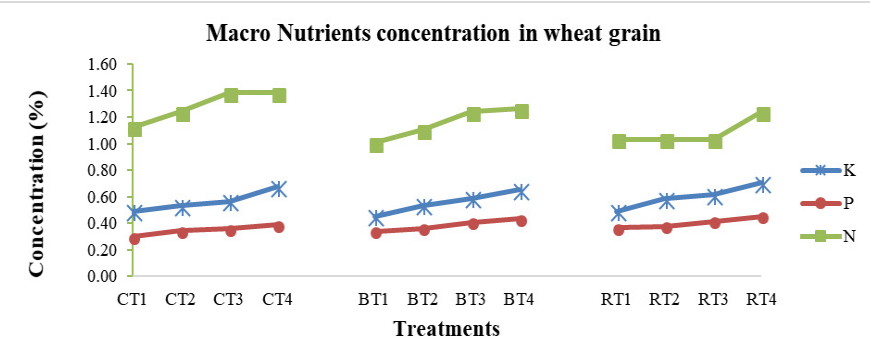

Figure 3: Effect of Crop residues Management Techniques on Macronutrients concentration in grain.

Effect of crop residues management techniques on nutrients uptake by wheat (grain and straw)

Six years pooled analysis (Figure 4) showed that Nutrient uptake was least in $T_{1}$ in all plots which increased gradually. In $\mathrm{T}_{4}$ nutrients maximum uptake was observed. N uptake in C plots was 148 to 345, $\mathrm{P}$ uptake was 104 to 256 while K uptake was 1080 to $2329 \mathrm{~kg} \mathrm{ha}^{-1}$. In B plots N uptake was 109 to $258, \mathrm{P}$ uptake was 89 to 201 while K uptake was 717 to 1505 $\mathrm{kg} \mathrm{ha}^{-1}$. In R plots $\mathrm{N}$ uptake was 179 to 382 , $\mathrm{P}$ uptake was 122 to 296 and $\mathrm{K}$ uptake was 784 to $1808 \mathrm{~kg} \mathrm{ha}{ }^{-1}$. It was observed that burning had deleterious effect on 
nutrients concentration in soil and uptake by plants. Residue's incorporation increased the nutrients uptake however; $\mathrm{K}$ uptake was greater in $\mathrm{C}$ plots than $\mathrm{R}$ and $\mathrm{B}$ plots. Burning of residues caused to reduce $\mathrm{N}$ uptake about 28 to $65 \%$, P uptake about 27 to 47 $\%$ and $\mathrm{K}$ uptake by 7 to $20 \%$.

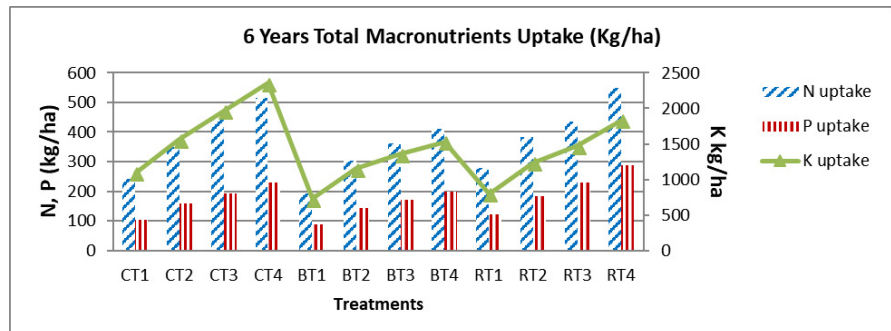

Figure 4: Effect of Crop residues Management Techniques on Nutrients uptake by wheat (grain and straw).

This study was conducted to compare the effect of three methods of residues management on the yield of wheat crop and soil physico-chemical properties. Organic matter contents were largely affected by the crop residues management practices. Burning of residues decreased the organic matter contents of soil up to $48 \%$ than residues incorporation. It was found that $\mathrm{OM}$ contents in control where no fertilizer was added were 23 and $24 \%$ greater in rotavated plots than complete removal and burnt plots. Application of fertilizers in recommended dose along with incorporating the residues increased the organic matter contents by 21 to $31 \%$ as compared to complete removal and burnt plots. Similar observations were recorded by another scientist (Humaira et al., 2018). Other scientist came with the view that, soil organic matter normally appears to slightly increase if residues are reimbursed to the soil, predominantly in the long period of time (Chenu et al., 2014; Autret et al., 2016; Merante et al., 2017).

Production cost of crops is increasing day by day due to high fertilizer prices in the country. At the same time, precious sources of organic matter (rice and wheat straw) are burnt by farmers that lead to poor fertility status and deterioration of soil physical properties. Under this scenario, it is dire need to include farm wastes in nutrition cycle. So FYM, sesbania and compost were added to soil alone and coupled with chemical fertilizers under rice-wheat system. It was concluded that usage of compost proved more pronounced than others. Growth and yield of rice and wheat were improved under the integration of organic and mineral fertilizers (Sarwar et al., 2008). Wheat was grown in salt stress environment. Different organic and mineral fertilizers were used as source of nutrition. These 2 different nutritional sources were used alone and in combination. It was observed that integrated use of both sources of nutrition proved best rather than their sole utilization (Sabah et al., 2014).

However,soilphosphorus and potassium concentration in soil was significantly $(\mathrm{P}<0.01)$ affected by crop residues management techniques. Incorporation of crop residues increased the available $\mathrm{P}$ contents about $14 \%$ than complete removal and $11 \%$ than burning technique, while burning had a deleterious effect on available phosphorus contents. Similar results were found by another scientist (Jharna et al., 2018).

Efficiency of various organic amendments (farmyard and poultry manure, filter cake press mud of sugar industry) was explored for the release of phosphorus from rock phosphate. It was noted from this experiment that release of phosphorus was enhanced much greater with the usage of these organic sources of nutrition for maize plants. Usage of press mud remained superior to others (Sabah et al., 2014).It was observed reasonable improvement in different growth parameters of rice and wheat when different organic amendments like green manure, farm yard manure and compost were applied to the soil in combination with mineral fertilizers as source of nutrition (Sarwar et al., 2009).

Crop's residues management practices and fertilizers rates had significant influence on wheat grain yield. Incorporation of rice residues increased the wheat yield about $5 \%$ than complete removal and up to $15 \%$ than residues burning method, might be due to the increase in soil organic matter, availability of nutrients and more water holding capacity which had effect on supply of nutrients (Humaira et al., 2018; Haunge et al., 2013). Burning of residues decreased the yield by $11 \%$ than complete removal and $17 \%$ than residues incorporation. Increase in $\mathrm{N}, \mathrm{P}$ and $\mathrm{K}$ uptake in incorporated plots may be due to the availability of nutrients in soil (Sharma, 2002).

\section{Conclusions and Recommendations}

The findings of this field experiment clearly reveal the handling of organic wastes on one hand and management of these crop residues in a way which not only improves the soil properties for better nutrients uptake and improved crop yield but it also mitigates the 
issues related to adversely changing climate scenario on other hand. It correlates different management practices for improving soil $\mathrm{C}$-sequestration for improved and sustainable agriculture in addition to lessening the adverse and negative impact of burning of crop residue on climate. It may assist the policy makers, researcher and even the growers/farmers. This experiment links different management strategies or alternative practices for managing crop residues and even these might improve soil organic contents for sustainable agriculture. The understanding of nutrients dynamics along with better soil organic contents assists to shift from conventional practices of handling crop residues to new and innovative practices, in rice-wheat based cropping systems and other agro-ecological systems of the world which also alleviate the problems of global warming, through reduced emission of greenhouse gases $\left(\mathrm{GHG}_{\mathrm{s}}\right)$. So, it might be concluded from this residue management study that soil incorporation of rice straw/residues not only improves soil, plant and grain production of rice but it also leads to the cleaning of our blanket (atmosphere), the planet earth.

\section{Novelty Statement}

Incorporation of crop residues not only improves soil, plant and grain production of rice but it also leads to the cleaning of our blanket atmosphere.

\section{Author's Contribution}

Aamer Sattar and Sadia Sultana: Conception and design of work and conducted experiment.

Abid Niaz: wrote Draft and technical assistance.

Muhammad Aftab and Irfan Rasheed: worked for Interpretation of data and excel work for graphs making.

Ghulam Sarwar: Overall supervised and guided about manuscript write up.

Muhammad Shoaib and Raheela Naz: Helped in lab. work.

Amina Kalsom: Participated in introduction portion Nisa Mukhtar: Participated in materials and methodology portion.

Farah Rasheed and Arfan ul Haq: Elaborated results and discussion.

Munazza Rafique: Arranged references as per journal format.

Muhammad Arif and Sarfraz Hussain: Final editing and proof reading.
Jafar Salim: Wrote Statistical analysis of data.

Conflict of interest

The authors have declared no conflict of interest.

\section{References}

Asal, K., S.A. Kazemeini and M.J. Bahrani. 2015. Wheat yield and soil properties as influenced by crops residues and nitrogen rates. Aust. J. Crop Sci., 9(9): 853-858.

Autret, B., B. Mary, C. Chenu, M. Balabane, C. Girardin, M. Bertrand, G. Grandeau and N. Beaudoin. 2016. Alternative arable cropping systems: a key to increase soil organic carbon storage. Results from 16 year field experiment. Agric. Eco-Syst. Environ., 232: 150-164. https://doi.org/10.1016/j.agee.2016.07.008

Blake, G.R. and K.H. Hartge. 1986. Bulk density. In: Methods of soil analysis, Part 1: Physical and mineralogical methods. Am. Soc. Agron., Madison, WI, USA; 1986.

Chapman, H.D. and P.F. Pratt. 1961. Methods of analysis for soils, plants and water. Univ. California, Berkeley, CA, USA.

Chenu, C., K. Klumpp, A. Bispo, D. Angers, C. Colnenne and A. Metay. 2014. Stocker du carbone dans les sols agricoles: Évaluation de leviers d'action pour la France. Innov. Agron., 37: $23-37$.

Erenstein, O., 2002. Crop residue mulching in tropical and semi-tropical countries: An evaluation of residue availability and other technological implications. Soil and Tillage Res., 67: 115-133. https://doi.org/10.1016/ S0167-1987(02)00062-4

Fegeria, N.K., V.C. Baliger and C.A. Jones. 1997. Growth and mineral nutrition of field Crops, New York, USA.

GOP. 2019-20. GoP, Econ. Surv. Pak., 2020. pp. 21.

Gupta, P.K, S. Sahai, N. Singh, C.K. Dixit, D.P. Singh, C. Sharma, M.K. Tiwari, R.K. Gupta and S.C. Garg. 2004. Residue burning in ricewheat cropping system: causes and implications. Curr. Sci., 87(2): 1713-1717.

Hartley, C. and C.V. Kessel. 2005. Residue management, soil organic matter and fertility in California rice systems. Conference Proceedings, California Plant and Soil Conference, California Chapter of the American Society of Agronomy, 
Modesto Double Tree Hotel, $11509^{\text {th }}$ Street, Modesto, California.

Haunge, Q. S. Laixiang, X. Xinliang, C. Yaqing and B. Junfei, 2013. Effect of residue retention on paddy crop. Soil Biol. Biochem., 64: 110-123.

Heard, J., C. Cavers and G. Adrian. 2006. Up in smoke nutrient loss with straw burning. Better Crops, 90: 10-11.

Hossein, S. and M.J. Bahrani. 2009. Effect of crop residues and Nitrogen rates on yield and yield components of two dryland wheat cultivars. Plant Prod. Sci., 12(4): 497-502. https://doi. org/10.1626/pps.12.497

Humaira, Y., M. Yaseen, M.Z. Aziz, M. Naveed, M.A.U. Haq, G. Jillani, A. Qadeer and T. Abbas. 2018. Wheat Residue Management Improves Soil Fertility and Productivity of Maize. Int. j. Agric. Biol. ISSN Print: 1560-8530; ISSN Online: 1814-9596 171191/2018/20-10-2181-2188.

Jackson, M.L., 1962. Chemical composition of soil. In: Chemistry of Soil (ed) Bean EF Van Notstrand Co, New York; pp. 71-144.

Jharna, R., B. Sarkera, P.S. Bhupinder, J. Warwick, Y. F. Doughertyb, B. Warwick, C. Frances, R.C. Hoyled, A.L. Dalalef and G. Cowiea. 2018. Impact of agricultural management practices on the nutrient supply potential of soil organic matter under long-term farming systems. Soil Tillage Res., 175: 71-81. https://doi. org/10.1016/j.still.2017.08.005

Kumar, P., 2014. Socioeconomic and environmental implications of agricultural residue burning, Springer Briefs in Environmental Science. https://doi.org/10.1007/978-81-322-2014-5

Mclean, E.O., 1982. Soil $\mathrm{pH}$ and lime requirement. In: Methods of Soil Analysis, Part 2: Chemical and microbiological properties. Page AL, Miller RH, Keeney DR (eds.). Am. Soc. Agron., Madison, WI, USA. 199-209. https://doi. org/10.2134/agronmonogr9.2.2ed.c12

Merante, P., C. Dibari, R. Ferrise, B. Sánchez, A. Iglesias, J.P. Lesschen, P. Kuikman, J. Yeluripati, P. Smith and M. Bindi. 2017. Adopting soil organic carbon management practices in soils of varying quality: implications and perspectives in Europe. Soil Tillage Res., 165: 95-106. https:// doi.org/10.1016/j.still.2016.08.001

Nyborg, M., E.D. Solberg, S.S. Malhi and R.C. Isauralde. 1995. Fertilizer N, crop residue, and tillage alter soil $\mathrm{C}$ and $\mathrm{N}$ content in a decade.
In: Advances in soil science: Soil Management and Greenhouse Effect, Lal, R., J. Kimble, E. Levine and B.A. Stewart (eds.). CRC Press, Inc., Boca Raton, Florida, USA. pp: 93-101. https://doi.org/10.1201/9780203739310-8

Nziguheba, G., C.A. Palm, R.J. Buresh and P.C. Smithson. 1998. Soil Phosphorus Fractions and Adsorption as affected by Organic and inorganic sources. Plant Soil, 1998: 159-168. https://doi.org/10.1023/A:1004389704235

Palm, C., H.B. Canqui, F. DeClerck, L. Gatere and P. Grace. 2013. Conservation agriculture and ecosystem services: An overview. Agric., Ecosyst. Environ., 187: 87-105. https://doi. org/10.1016/j.agee.2013.10.010

Paudel,B.,B.S.Acharya, R.Ghimire,K.R.Dahal and P. Bista. 2014. Adapting Agriculture to climate change and variability in chitwan: Long-term trends and farmers' perceptions. Agric. Res., 3: 165-174. https://doi.org/10.1007/s40003-0140103-0

Rajan, G., L. Sushil, S.A. Bharat, B.U. Prakriti and M. Sainju. 2016. Tillage, crop residue, and nutrient management effects on soil organic carbon sequestration in rice-based cropping systems: A review. J. Integ. Agric., 15(0): 603457.

Rieger, S., W. Richner, B. Streit, E. Frossard and M. Liedgens. 2008. Growth, yield, and yield components of winter wheat and the effects of tillage intensity, preceding crops and $\mathrm{N}$ fertilization. Eur.J.Agron., 28: 405-411.https:// doi.org/10.1016/j.eja.2007.11.006

Rowell, D.L., 1994. Soil science. Methods and Application Longman Scientific and Technical, UK.

Ryan, J., G. Estefan and A. Rashid. 2001. Soil and plant analysis laboratory manual. $2^{\text {nd }} \mathrm{Ed}$. International Center for Agricultural Research in Dry Areas, Alleppo, Syria.

Sabah, N.U., G. Sarwar and M.A. Tahir. 2014. Role of various nutritional sources for improving the yield of wheat under saline-sodic soil environment. Pak. J. Agric. Sci., 51(4): 963-967.

Sabah, N.U., G. Sarwar, M.A. Tahir and S. Muhammad.2018. Depicting the role of organic amendments for bio available phosphorus release from different sources of rock phosphate and uptake by maize crop. Pak. J. Bot., 50(1): 117-122.

Sarwar, G., N. Hussain, A.R. Naseem and F. 
Mujeeb. 2009. Comparison of different sources of organic material for enhancing yield of rice and wheat crops. Int. J. Agric. Appl. Sci., 1(1): 9-12.

Sarwar, G., N. Hussain, H. Schmeisky and S. Muhammad.2008. Efficiency of various organic residues for enhancing rice-wheat production under normal soil conditions. Pak. J. Bot., 40(5): 2107-2113.

Sharma, S.N., 2002. Nitrogen management in relation to wheat residues management in ricewheat cropping system. Indian J. Agric. Sci., 72: 449-452.

Soon, Y.K., 1998. Crop residue and fertilizer management effects on some biological and chemical properties of a Dark Grey Solod. Can. J. Soil Sci., 78: 707-713. https://doi. org/10.4141/S98-016

Sparks, D.L., A. Page, P.A. Helmke, R.H. Loeppert, P.N., Soltanpour, M.A. Tabatabai, C.T.Johnson and M. Sumner. 1996. Methods of soil analysis: Part 3-chemical methods. Book Series Number 5. Soil Sci. Soc. of Am., Am. Soc. of Agron; Madison, WI, USA. https://doi.org/10.2136/ sssabookser5.3

Steel, R.G.D., J.H. Torrie and D.A. Dicky. 1997. Principles and procedures of statistics, $3^{\text {rd }} \mathrm{Ed}$.
McGraw Hill. Inc. Book Co. New York (USA), pp. 352-358.

Stevenson, J.R., N. Villoria, D. Byerlee, T. Kelley and M. Maredia. 2013. Green revolution research saved an estimated 18 to 27 million hectares from being brought into agricultural production. Proc. Natl. Acad. Sci. U.S.A., 110: 8363-8368. https://doi.org/10.1073/ pnas.1208065110

Surekha, K., A.P.P. Kumari, M.N. Reddy, K. Satyanarayana and P.C.S. Cruz. 2003. Crop residue management to sustain soil fertility and irrigated rice yields. Nutr. Cycl. Agroecosyst., 67: 145-154. https://doi. org/10.1023/A:1025543810663

Vanden, B.A.J., E.G. Gregorich and D.A. Angers. 2003. Influence of agricultural management on soil organic carbon: A compendium and assessment of Canadian studies. Can. J. Soil Sci., 83: 363-380. https://doi.org/10.4141/ S03-009

Verma, T.S. and R.M. Bhagat. 1992. Impact of rice straw practices on yield, nitrogen uptake and soil properties in a wheat rice rotation in Northern India.Fertil. Res., 33: 97-106. https:// doi.org/10.1007/BF01051164 